\title{
The Evaluation of the Performance of Eastland Insurance Company Limited: A Study of Bangladesh
}

\author{
Bijoy Chandra Das, Soma Rani Sutradhar
}

Department of Finance and Banking, Jatiya Kabi Kazi Nazrul Islam University, Trishal, Mymensingh-2220

\begin{abstract}
AB S TR ACT
2015 Research Leap/Inovatus Services Ltd.

All rights reserved.

Keywords:

Insurance

Risk
\end{abstract}

Premium

Annuity

Re-insurance.

\section{Introduction}

From the beginning of the human society, man has wanted the safety for himself, for his family and for his next generation. Although such expectation of safety is natural, man has never been able to assure it. Human life is completely surrounded by various types of risks and perils. To cover the losses occurred from such type of risks and perils, the insurance business has been originated. Insurance is the system of spreading the risk of one to the shoulders of many. It can be defined as a co-operative device to spread the loss caused by a particular risk over a number of persons who are exposed to it and who agree to ensure themselves against that risk. It is a contract whereby the insurer, on receiving of a consideration known as premium, agrees to indemnify the insured against losses arising out of certain specified unforeseen contingencies or perils. It can play an important role in a country's economy. It is an old form of financial practice of sharing risk which was introduced in this area in mid- $18^{\text {th }}$ century.

Insurance business of Bangladesh has a long history of evolution. About a century back, couple of insurance companies started both non-life and life insurance business during the British regime in India. After the emergence of the People's Republic of Bangladesh in 1971, the government nationalized the insurance industry along with the banks in 1972 by Presidential Order No. 95. By virtue of this order, all companies and organization transacting all types of insurance business in Bangladesh came under this nationalization order. This was followed by creation of five insurance companies in the life and non-life sector. Further changes were brought on 14th May, 1973. Through the enactment of Insurance Corporation Act VI, 1973, this led to creation of two corporations namely Sadharan Bima Corporation for general insurance and, Jiban Bima Corporation for life insurance in Bangladesh. In other words, Sadharan Bima Corporation (SBC) emerged on 14th May, 1973 under the Insurance Corporation Act (Act No. VI) of 1973 as the only state owned organization to deal with all classes of general insurance $\&$ re-insurance business emanating in Bangladesh. Thereafter SBC was acting as the sole insurer of general insurance till 1984. Bangladesh government allowed the private sector to conduct business in all areas of insurance for the first time in 1984. The private sector availed the opportunity promptly and came forward to establish private insurance companies through promulgation of the Insurance Corporations (Amendment) Ordinance (LI of 1984) 1984.

The Insurance Market in Bangladesh now consists of two stateowned corporations, a total of 77 insurance companies. Thus, the insurance sector in Bangladesh has grown up substantially and deepened remarkably with number of companies in both life and general segments. With the expansion of size of the insurance market, the volume of assets of the industry has also increased substantially. SBC is entitled to $50 \%$ of public sector business. Insurance Corporation (Amendment) Act 1990 provides that fifty percent of all insurance business relating to any public property or to any risk or liability appertaining to any public property shall be placed with the SBC and the remaining fifty percent of such business may be placed with this corporation or with any other insurers in Bangladesh. But for practical reason and in agreement with the Insurance Association of Bangladesh, SBC underwrites all the public sector business and $50 \%$ of that business is distributed among the existing 43 private general insurance companies equally under National Co-insurance Scheme. In respect of reinsurance, the same act provides that fifty percent of a company's reinsurance business must be placed with the 
Sadharan Bima Corporation and remaining fifty percent may be reinsured either with this Corporation or with any insurer in Bangladesh or abroad. At present, nearly all the companies place $100 \%$ of their reinsurance business with the SBC. The activities of main two insurance companies are:

1. Sadharan Bima Corporation for transacting general insurance business only. The two general insurance corporations were merged under it.

2. Jiban Bima Corporation for transacting life insurance business only. The two life insurance corporations were merged under it.

\subsection{Objective of the Research}

This research is conducted on Eastland Insurance Company Limited. It is accomplished on the "The Evaluation of the policies and performance of Eastland Insurance Company Limited". This study also includes the information on the overview of Eastland Insurance Company Limited, theoretical analysis of insurance and legal framework of Bangladesh on insurance industry. This study is prepared primarily to have clear and real life ideas about the position of Eastland Insurance Company in insurance sector of Bangladesh.

The objectives of the study are following:

1. To know about the current situation of insurance business in Bangladesh;

2. To measure the efficiency of insurance business in Bangladesh;

3. To know the reason behind the inefficiency of insurance business in Bangladesh.

\subsection{Methodology including detailed analysis plan and sample data collection instruments}

Correct and smooth completion of research work requires adherence to some rules and methodologies. In order to conduct the research, we have decided to collect various types of primary and secondary data. Different form of statistical configurations such as percentages rates and ratios has been used to make the study meaningful and realistic.

After collecting data from the interview and interview data has been first carefully scrutinized. Then the data was organized as required. In order to make the study effective and efficient, following two sources of data have been used widely.

\section{(a) Primary information/data:}

The primary data have been collected by oral interviewing the responsible officers and staffs of the Eastland Insurance Company Ltd. We also get the primary information by observing the various departments of the Eastland Insurance Company Ltd.

\section{(b) Secondary Information/data}

The main source of published data is the auditors' statements of financial affairs, which are basically used internally by the corporation. Data are also collected from secondary sources likeAnnual Reports, Bangladesh Insurance Academy and Insurance Development \& Regulatory Authority etc.

\subsection{Sampling procedure and sample sizes}

The following steps will be followed

Step-1: Eastland Insurance Company Limited has to be selected; Step-2: Annual reports of last ten years will be collected;

Step-3: Website of Eastland Insurance Company Limited will be shown.
Step-4: Over phone conversation with officers of Eastland Insurance Company Limited will be conducted.

\subsection{Analysis plan: Descriptive and inferential analysis}

An eloquent analysis of data will be made using sound statistical tools like graphs, t-test, AVOVA, correlation, regression and ratio analysis will be used. Relative important issues will be identified and analyzed. In order to meaningful analysis of the data, appropriate statistical tools will be used. It is noted that comparative analysis and previous study findings will be attempted. The study will follow the descriptive and inferential analysis.

\section{Literature review}

Murshid, M.M. (1993), stated that insurance is not a new idea or proposition to the people of Bangladesh. About half a century back, during the British regime in the then India, some insurance companies started insurance business, particularly life, in this part of the world. Since 1947 until 1971 insurance business gained momentum in this part of what was then known as East Pakistan. There were about 49 companies transacting both life and general insurance business. These companies were operating under a free competitive economy.

Bhuiyan, B.A, Ali, K.M.M, Nurnnabi, M.A.A and Ahmed, T. (2003), stated that while in the developing country both the Government and the financial institutions endeavor to dig deep in to the insurance fund for gainful utilization in various nation building activities like industrial financing, social and infrastructure.

Janowicz- Lomott (2011) stated that role of insurance investment management as to manage the funds generated by the insurance business, maximizing risk adjusted returns while meeting regulatory requirements on its assets and other financial constraints. The author further states that insurance investment management must ensure that investment returns preserve the solvency, both regulatory and economic, of the insurance company, earn the return commensurate with the use of its capital and enable it to continue to underwrite profitable insurance business.

Oyatoye \& Arileserre (2012), stated that as it is crucial for insurance industry to survive and develop, the insurance investment enables insurance companies to offset their Possible underwriting losses and make a considerable profit. Based on the above literature, we can say that there are some studies about banks in various countries, however a detailed study has not yet been conducted in Bangladesh context, especially banking sectors.

\section{Theoretical Analysis}

Insurance: In a simple sense, Insurance is nothing but a process of risk management. In a broad sense, Insurance is the system of spreading the risk of one to the shoulders of many. Insurance is a co-operative form of distributing a certain risk over a group of persons who are exposed to it (M. K. Goash\& A. N. Agarwala).

Risk: Insurance is a co-operative device to spread the loss caused by a particular risk over a number of persons, who are exposed to it and who agree to insure themselves against the risk (M. N. Mishra). For example: We usually say risk of death and not risk of survival as death is something which is never desired. 


\section{Premium:}

In simple sense, premium means an additional payment. Premium means an amount or money to be paid regularly for an insurance policy (Oxford Dictionary of Business).

Insurance premium means annual payment made by a person or a company to an insurance company (P. H. Collin).

Essential Elements of the Contract of Insurance are:

Plurality of Members: In any contract there must be at least two or more parties. Similarly, for an insurance contract, there must be two or more parries. One party is insured and another is insurer.

Offer and acceptance: For a valid contract it is necessary that, one party make offers and another party accept that offer. In an insurance contract, insurance make offer by applying through application and the insurer accept that offer by recognizing that application.

Legal relationship: After making a contract there creates a relation of law among the parties. Such relationship means that relationship which can be applicable bylaw. If any party breaks the contract, then another party can take legal action against that party.

Lawful consideration and object: The crucial elements of contract are the validity of consideration and object. In case of an insurance contract, the consideration of both parties must be valid. The object of the contract also must be valid.

Capacity to contract of the parties: Like general contract in case of insurance contract there must be the capability of parties to make contract. According to section 11 of Contract Act 1972, every person is capable of making contract if

- He is not a minor;

- He is not a unsound minded; and

- He is incapable of making contract according to the declaration of Act

Free consent: In an insurance contract there must be free consent of every party. According to section 14 of Contract Act 1972, free consent refers to the consent that are not made by any type of coercion, undue influence, fraud, misrepresentation, errors etc.

Certainty: According to section 29 of Contract Act 1972, any contract will be invalid if the subject matter is certain. In case of insurance contract, all things of contract must be certain and specific.

Written contract: In case of an insurance contract the contract must be written. So the insured must fill up the insurance form.

Insurable interest: In every insurance contract, there must be insurable interest of the insured. Insurable interest refers to the financial interest of insured which means if there cause any harm to the subject matter of the insurance then the insured will be hampered and if there cause no harm to the subject matter of the insurance then the insured will be benefitted.

Fiduciary relationship: In case of insurance, there established a fiduciary relationship between the insured and insurer. So here every party is bound to provide all necessary information to each other.
Payment of premium: In case of insurance the insured will pay premium to the insurer in exchange of taking risk by the insurer. It is another element of insurance contract.

Financial indemnity or payment: Insurance is the system of financial indemnity against probable risk. If there occurs any hazard then insurance company will indemnify to the insured.

Causaproxima: The insurance company will provide indemnification to the insured only if there occurred loss due to the risks that are mentioned in the contract paper of insurance. Otherwise the insurance company is not liable to make indemnification.

Proportionate contribution: Insurance of same assets can be made to more than one insurance company. In this case, if there occurs any loss to that asset, then all the insurer company will indemnify proportionately.

Subrogation: In case of fire or marine insurance, if there occurs any loss to the subject matter than the insurance company will indemnify to the insured and the insurance company will be the owner of the rest of that subject matter.

Annuity: An annuity is a periodical level payment made in exchange of the purchase money for the remainder of the life time of a person or for a specified period (M. N. Mishra).

Surrender value: Surrender value is that amount of premiums paid which is returned to the policy-holder at the time of surrendering the policy (M. N. Mishra).

Jettison: Jettison means to throw cargo from a ship into the sea to make the ship lighter (P. H. Collin).

Double Insurance: If the insured makes insurance of same assets to more than one insurance companies then the insurance policy is known as Double insurance. Generally, in these types of insurance, the insured amount is large amount and the subject matter is more precious.

Re-insurance: Re-insurance is an arrangement whereby an original insurer who has insured a risk, insures a part of that risk again with another insurer (M. N. Mishra).

\section{Present position of insurance business in Bangladesh}

In Bangladesh, the Insurance business, after an early stage of dislocation, adventure and experimentation through half a century has now being established as a nascent industry distributed between the public and private sectors. Insurance business evolved in the Indian subcontinent late in nineteenth century when several business companies started their business and a few Christian missionaries began to operate mutual funds to serve their own community members. From Bangladesh perspective insurance business was not a promising sector in its early age but it is getting its pace day by day with the growth of overall economic condition of the country. The privatization policy adopted in the 1980s paved the way for a number of insurers to emerge in the private sector. This resulted in a substantial growth of premium incomes, competition, improvement in services, and introduction of newer types of business in wider fields hither to untapped. Up to 2000 , the government has given permission to 19 general insurance companies and 10 life insurance companies in the private sector. Insurers of the country now conduct almost all types of general 
and life insurance, except crop insurance and export credit guarantee insurance, which are available only with the Eastland Insurance Company Ltd. Numerous institutions, associations and professional groups work to promote the development of insurance business in Bangladesh. Prominent among them is the Bangladesh Insurance Association (formed on 25 May 1988) having 30 members. It aims at promoting, supporting and protecting the interests and welfare of the member companies. Another example is Bangladesh insurance academy. Surveyors and insurance agents occupy a prominent position in the insurance market of Bangladesh. The system of professional brokers has not yet developed in Bangladesh. A total of 60 insurance companies are operating in Bangladesh till date. Of these companies, 57 are private, two state-owned and one is foreign.

Insurance Directorate, under the Ministry of Commerce, is the regulatory-body of the country's insurance sector. At present there are 44 general insurance companies running in Bangladesh. Many other private companies are about to commence.

\section{Overview of Eastland Insurance Company}

Eastland Insurance Company Limited started its journey as one of the first generation General Insurance Companies in the private sector from 05 November 1986. Eastland was listed as a public company with Dhaka Stock Exchange (DSE) in 1994 and its Tk. 30 million shares with $40 \%$ premium were oversubscribed by more than 12 times. Ever since, its performance remained steady with continuous growth. The total asset of the Company is over Tk. 1900 million having a reserve base of about Tk. 760 million and investment portfolio of Tk. 803 million. The company has so far settled claims amounting to Tk. 1879 million and has been paying ,double digite dividends to its shareholders ever since its inception plus stock bonus from time to time.

The fundamental principle followed by the company from the very inception was to maintain the dynamism in its business policy as well as a competitive edge in the market through service innovation and obtaining best bargain from the global market of re-insurance. Eastland has been offering a comprehensive range of insurance packages from its 25 branches throughout Bangladesh, which includes Fire, Marine, Hull, Motor, Industrial All Risk, Engineering, Aviation, Contractor's All Risks (CAR), Overseas Mediclaim Scheme and Miscellaneous Risks.

Eastland Insurance has always been quite conscious in its Corporate Social Responsibility (CSR). Apart from several contributions to social cause, it has provided educational scholarships to the needy \& deserving students, provided Medical Equipment to Hospitals, extended donations to the
Prime Minister's Relief Fund and contributed towards the victims of RANA PLAZA disaster. Eastland also provided support to the local burn victims of Nimtoli fire and Earthquake victims of the Republic of Nepal.

The Credit Rating Information and Services Limited (CRISL) have affirmed "AA" Credit Rating to Eastland for three consecutive years. The Institute of Cost and Management Accountants of Bangladesh (ICMAB) awarded Eastland with the "Best Corporate Award" in the General Insurance sector for last three consecutive years. Eastland was also awarded "Certificate of Merit" by the Institute of Chartered Accountants of Bangladesh (ICAB) for the "Best presented Annual Report 2013" as a mark of recognition of Excellence in the General Insurance Sector.

The company stepped into 30 years of its successful operation on the 5th of November, 2015 and has by now attained the height of sound financial strength and enviable goodwill, thus being categorized among the „Top-ten ${ }^{\text {ee }}$ in the general insurance sector. The management of the company is a combination of astute executives with wealth of experience as well as young and dynamic leaders of today; to meet the challenges of tomorrow. The company is living up to its promised slogan: "The name you have learnt to Trust" by upholding its personalized services in both Sunny \& Rainy days. As such, Eastland's name has been embedded in the hearts of thousands of its clients.

\section{Data Analysis}

\subsection{Ratio Analysis:}

\section{Short term Solvency Position of Eastland Insurances Company Limited:}

Liquidity ratios measure the firm's ability to fulfill short-term commitments out of its liquid assets. The most commonly used measures of liquidity are the current ratio, acid test ratio. Current ratio is a measure of the firm's ability to raise funds to meet short-run obligations. If the current ratio is too low, the firm may have difficulty in meeting short-term commitments as they mature. If the ratio is too high, the firm may have an excessive investment in current assets or be underutilizing short term credit. An ideal current ratio is 2:1. Acid test ratio measures the firm's ability to meet short-term obligations from its most liquid assets without any difficulty. An ideal acid test ratio is 1:1. Against this back drop, the following table shows the position of short-term solvency of Eastland Insurance Ltd. of the selected years.

Table 1: Position of Current Ratio \& Acid test Ratio of Eastland Insurance Company Ltd. during the period 2004 to 2013

\begin{tabular}{|l|l|l|l|l|l|l|l|l|l|l|l|}
\hline Ratios/Year & 2004 & 2005 & 2006 & 2007 & 2008 & 2009 & 2010 & 2011 & 2012 & 2013 & 2014 \\
\hline Current ratio & 4.14 & 4.20 & 3.75 & 4.77 & 3.26 & 3.01 & 3.08 & 1.37 & 4.53 & 3.96 & 4.1 \\
\hline $\begin{array}{l}\text { Acid Test } \\
\text { Ratio }\end{array}$ & 3.14 & 3.21 & 2.76 & 3.78 & 2.27 & 2.01 & 2.08 & 0.366 & 3.53 & 2.96 & 3.2 \\
\hline
\end{tabular}

would be unable to pay off its obligations if they came due at that

Current Ratio: The ratio is mainly used to give an idea of the company's ability to pay back its short-term liabilities (debt and payables) with its short-term assets (cash, inventory, receivables).

The higher the current ratio, the more capable the company is of paying its obligations. A ratio under 1 suggests that the company point. While this shows the company is not in good financial health, it does not necessarily mean that it will go bankrupt - as there are many ways to access financing - but it is definitely not a good sign. 


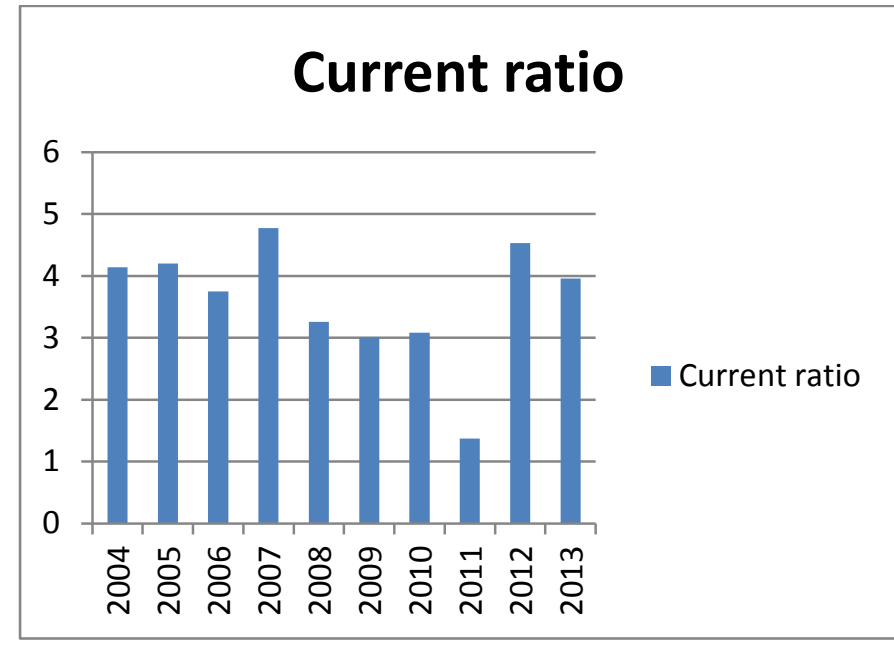

Acid-Test Ratio: A stringent indicator that determines whether a firm has enough short-term assets to cover its immediate liabilities without selling inventory. The acid-test ratio is far more strenuous than the working capital ratio, primarily because the working capital ratio allows for the inclusion of inventory assets.

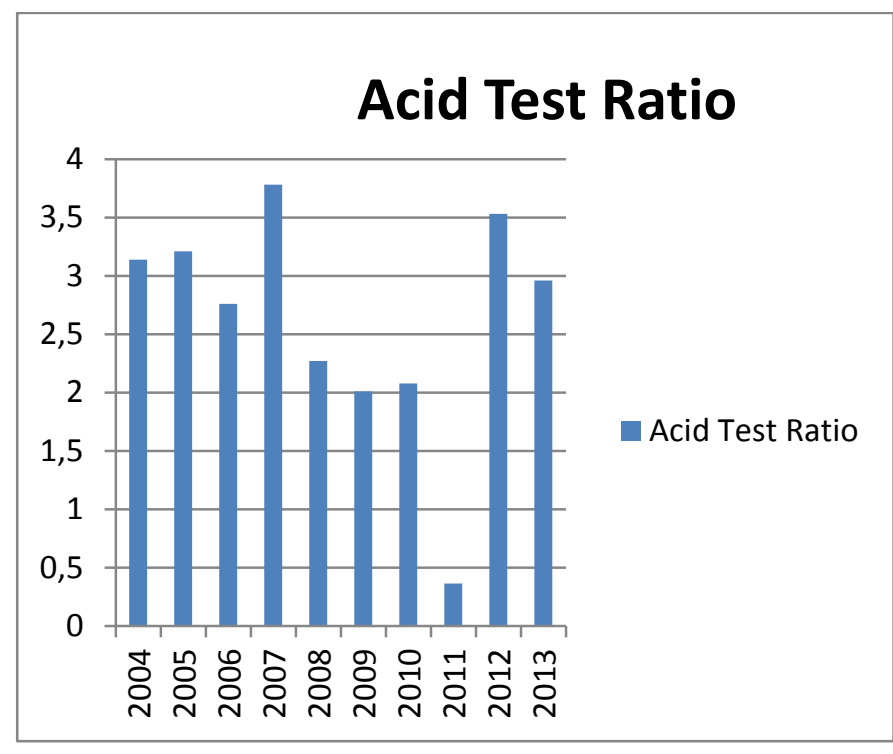

Examination of Long-term financial position of Eastland Insurance Company Ltd.:

To judge the long term financial position of the firm, financial leverage ratios are calculated. These ratios indicate mix of funds provided by owners and lenders. The long term financial solvency of a firm can be measured by using the ratios; i) Debt to total asset ratio ii) Debt-to equity ratio and iii) Capital employed to net worth ratio. Debt to total asset ratio equals total debt divided by total assets. Generally, creditors prefer a low debt ratio since it implies a greater protection of their position. A higher debt ratio means that the firm must pay a higher interest rate on its borrowing, beyond some point; the firm will not be able to borrow at all. Debt to equity ratio is used to ascertain the soundness of the long term financial policies of the company. This ratio is to indicate the extent of operating profits that cover the fixed interest charges. The fixed interest charge will signify the long term solvency of the firm. Capital employed to net worth ratio implies that how much funds are being contributed together by lenders and owners for each taka. This can be found out by calculating the ratio of capital employed or net assets (NA) to net worth (NW).

\begin{tabular}{|l|l|l|l|l|l|l|l|l|l|l|}
\hline Ratios/Year & 2004 & 2005 & 2006 & 2007 & 2008 & 2009 & 2010 & 2011 & 2012 & 2013 \\
\hline $\begin{array}{l}\text { Return on capital } \\
\text { Employed ratio }\end{array}$ & 81.17 & 64.62 & 58.75 & 69.21 & 63.75 & 64.42 & 69.83 & 77.42 & 63.17 & 52.68 \\
\hline $\begin{array}{l}\text { Debt to equity } \\
\text { Ratio }\end{array}$ & 1.36 & 1.02 & 1.07 & 0.940 & 0.744 & 0.837 & 0.715 & .415 & 0.937 & 0.811 \\
\hline $\begin{array}{l}\text { Debt total asset } \\
\text { Ratio }\end{array}$ & .709 & 0.709 & 0.711 & 0.600 & 0.599 & 0.634 & 0.599 & .222 & 0.644 & 0.625 \\
\hline
\end{tabular}

Return On Capital Employed (ROCE): A financial ratio that measures a company's profitability and the efficiency with which its capital is employed.

Return on Capital Employed $($ ROCE) $=$ Earnings before Interest and Tax (EBIT) / Capital Employed

"Capital Employed" as shown in the denominator is the sum of shareholders' equity and debt liabilities; it can be simplified as (Total Assets - Current Liabilities). Instead of using capital employed at an arbitrary point in time, analysts and investors often calculate ROCE based on "Average Capital Employed," which takes the average of opening and closing capital employed for the time period. A higher ROCE indicates more efficient use of capital. ROCE should be higher than the company's capital cost; otherwise it indicates that the company is not employing its capital. 


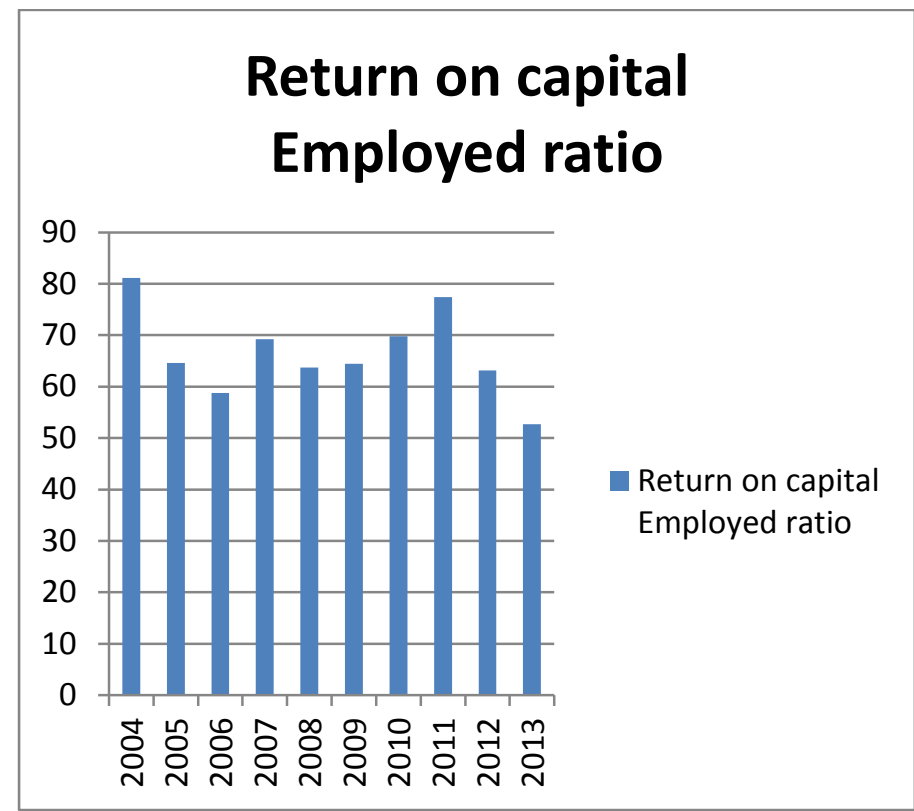

Debt to equity ratio: A measure of a company's financial leverage calculated by dividing its total liabilities by stockholders' equity. It indicates what proportion of equity and debt the company is using to finance its assets

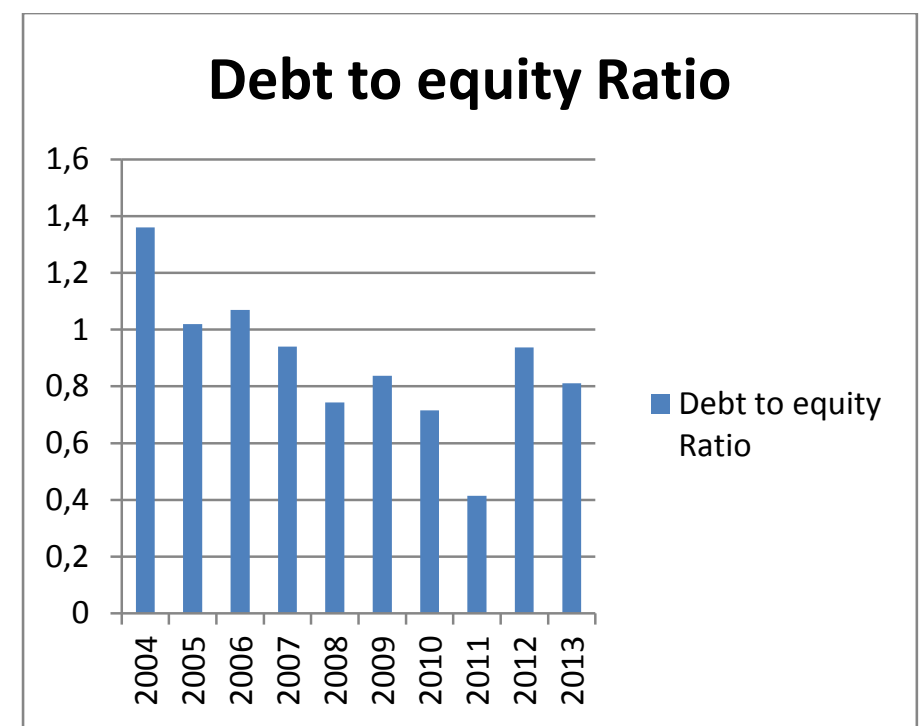

Debt to Total Assets: Total debt to total assets is a leverage ratio that defines the total amount of debt relative to assets. This enables comparisons of leverage to be made across different companies. The higher the ratio, the higher the degree of leverage, and consequently, financial risk. This is a broad ratio that includes long-term and short-term debt (borrowings maturing within one year), as well as all assets - tangible and intangible.

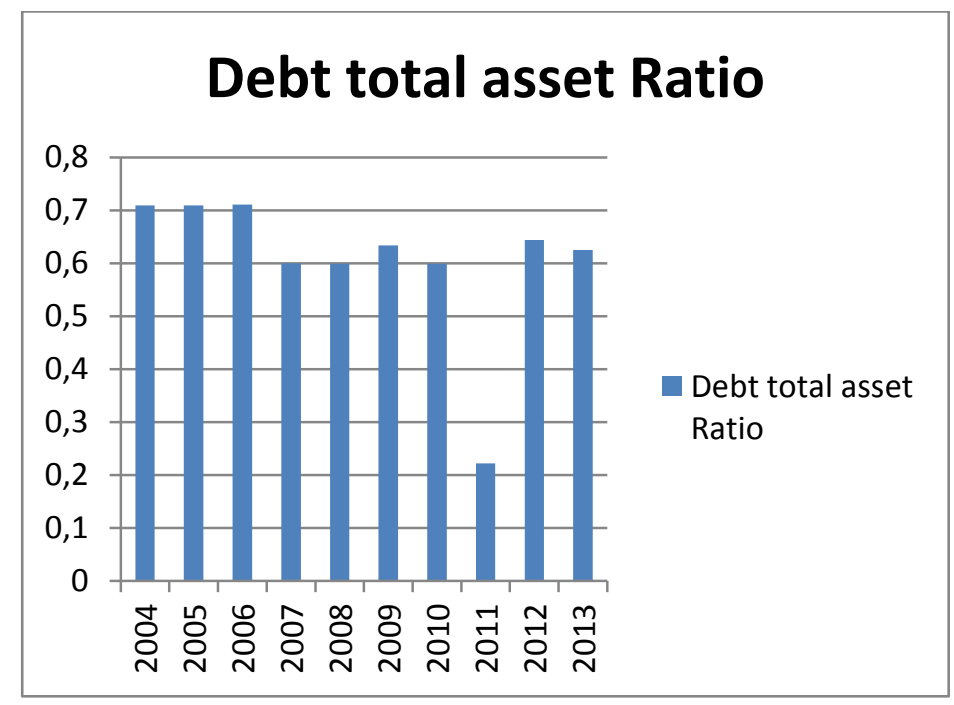

\section{Analysis of Activity/Efficiency position of Eastland} Insurances Company:

Activity ratios are also called Turnover ratios, efficiency ratios or asset utilization ratios. Because they indicate the speed with which assets are being converted or turn over to sales. The activity ratios: (i) Total Assets turnover ratio (ii) Fixed Assets turnover ratio. (iii) Current Assets turnover ratio have used as tools to judge the effectiveness of assets. Total assets turnover equals sales or net premium income divided by total assets. It reflects how well the company's assets are being used to generate sales or underwrite net premium. Fixed assets turnover is computed by dividing sales i.e. net premium income by net fixed assets. This ratio indicates how intensively the fixed assets of the firm are being used. Current assets turnover equals sales or net premium income divided by current assets.

Position of Total Asset turnover, Fixed Asset turnover and Current Asset turnover during the years 2004 to 2013.

\begin{tabular}{|c|c|c|c|c|c|c|c|c|c|c|}
\hline Ratios/Year & 2004 & 2005 & 2006 & 2007 & 2008 & 2009 & 2010 & 2011 & 2012 & 2013 \\
\hline $\begin{array}{c}\text { Fixed asset } \\
\text { turnover Ratio }\end{array}$ & 0.556 & 0.687 & 0.711 & 0.684 & 0.573 & 0.463 & 0.479 & .648 & 0.452 & 0.405 \\
\hline $\begin{array}{c}\text { Turnover to } \\
\text { total asset } \\
\text { Ratio }\end{array}$ & 0.232 & 0.253 & 0.272 & 0.249 & 0.261 & 0.229 & 0.246 & .230 & 0.224 & 0.221 \\
\hline
\end{tabular}

Source: Annual Report of Eastland insurances company during the years 2004 to 2013

Fixed Asset Turnover Ratio: A financial ratio of net sales to fixed assets. The fixed-asset turnover ratio measures a company's ability to generate net sales from fixed-asset investments specifically property, plant and equipment (PP\&E) - net of depreciation. A higher fixed-asset turnover ratio shows that the company has been more effective in using the investment in fixed assets to generate revenues. 
Fixed Assets Turnover Ratio of Eastland insurances company Ltd. from the years 2004 to 2013

\section{Fixed asset turnover Ratio}

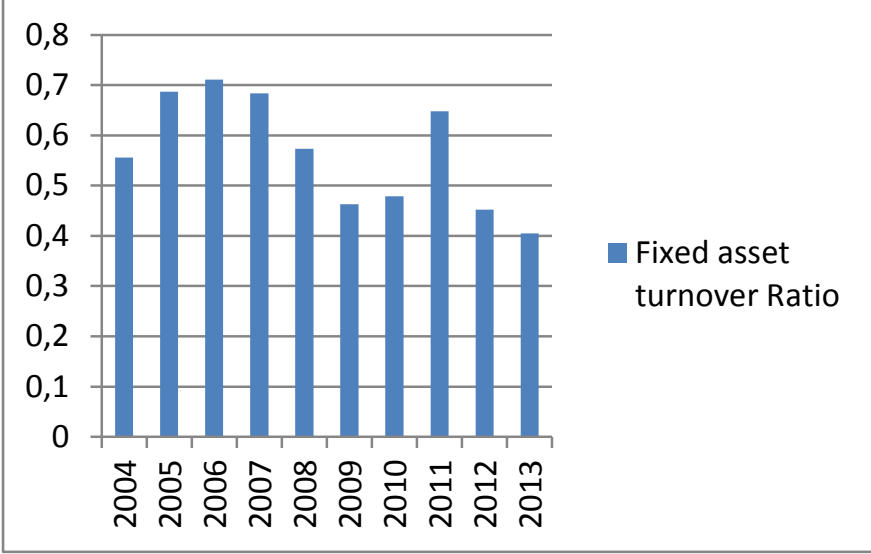

It can be said that from the above figure, the fixed assets turnover ratios are $.556,0.687,0.711,0.684,0.573,0.463,0.479,0.648$ , 0.452 and 0.405 during the period 2004-2013 and on an average it is .568 which is below the standard norm of 10 times the low fixed asset turnover ratio of Eastland insurances company resulted from poor sales performances.
Total asset Turnover Ratio of Eastland Insurances Company from the years 2004 to 2013

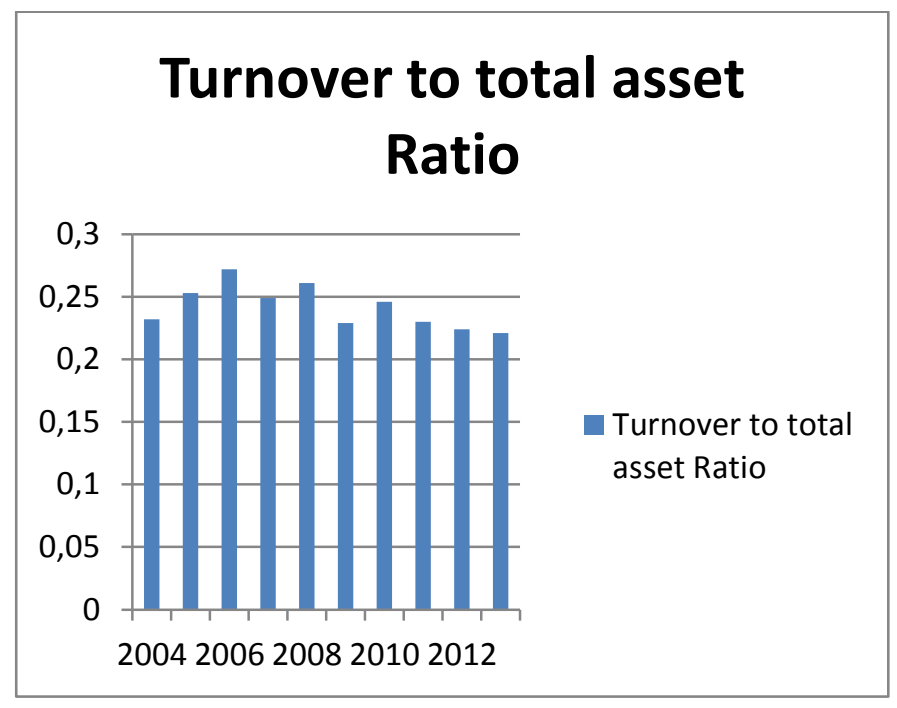

The above figure reveals that, the total asset turnover are 0.232 , $0.253,0.272,0.249,0.261,0.229,0.246,0.230,0.224$ and 0.221 during the study period 2004 to 2013 respectively and on an average it is 0.242 . The total asset turnover ratio is very low in Eastland Insurances Company Ltd. during the study period but it shows on improving trend. The low turnover ratio indicates to the underutilization of resources. The average total asset turnover of 0.242 times denotes that Eastland Insurance Company Ltd. generated a sale of general insurance policy or underwrote a net premium of Tk 0.242 for one taka investment in fixed and current asset together. It can be said that Eastland Insurances Company has more capacity in generating sales or underwriting net premium from all financial resources committed to total assets.

\section{Profitability Ratios as a yardstick for Evaluation:}

Profitability ratio measures the success of the firm in earning a net return on sates or on investment. Since, profit is the ultimate objective of the firm, poor performance here indicates a basic failure. The gross profit margin ratio, net profit margin ratio, return on investment and return on equity ratios are the four most acceptable profitability ratios in assessing financial performance of an enterprise. The following table shows the profitability position of the firm.

Table 2: Profitability position of Eastland Insurances Company Ltd. from the period 2004-2013

\begin{tabular}{|l|l|l|l|l|l|l|l|l|l|l|}
\hline Ratios/Year & 2004 & 2005 & 2006 & 2007 & 2008 & 2009 & 2010 & 2011 & 2012 & 2013 \\
\hline $\begin{array}{c}\text { Gross profit } \\
\text { Ratio }\end{array}$ & 38.22 & 42.82 & 31.84 & 49.45 & 44.42 & 49.05 & 62.88 & 80.23 & 61.16 & 63.27 \\
\hline $\begin{array}{c}\text { Net profit to } \\
\text { fixed total } \\
\text { asset }\end{array}$ & 1.60 & 0.89 & 0.66 & 0.53 & 10.63 & 18.94 & 27.28 & 42.10 & 19.97 & 21.36 \\
\hline
\end{tabular}

Gross Profit Ratio: Gross profit is very important for any business. It should be sufficient to cover all expenses and provide for profit. There is no norm or standard to interpret gross profit ratio (GP ratio). Generally, a higher ratio is considered better. The ratio can be used to test the business condition by comparing it with past years' ratio and with the ratio of other companies in the industry. A consistent improvement in gross profit ratio over the past years is the indication of continuous improvement. When the ratio is compared with that of others in the industry, the analyst must see whether they use the same accounting systems and practices 
Gross profit Ratio of Eastland insurances company Ltd. from the years 2004 to 2013

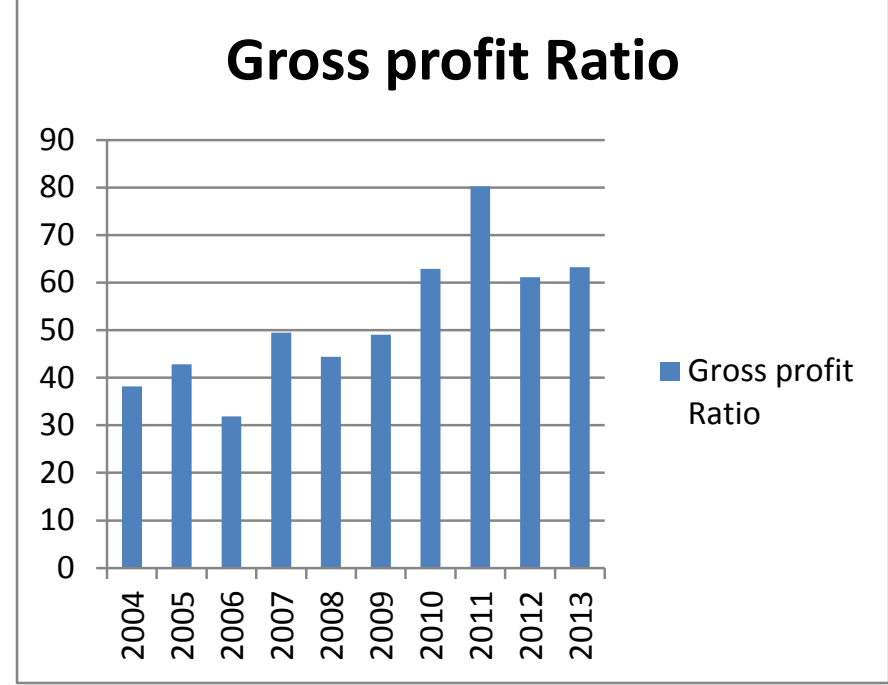

Net profit fixed total Ratio of Eastland insurances company Ltd. from the years 2004 to 2013

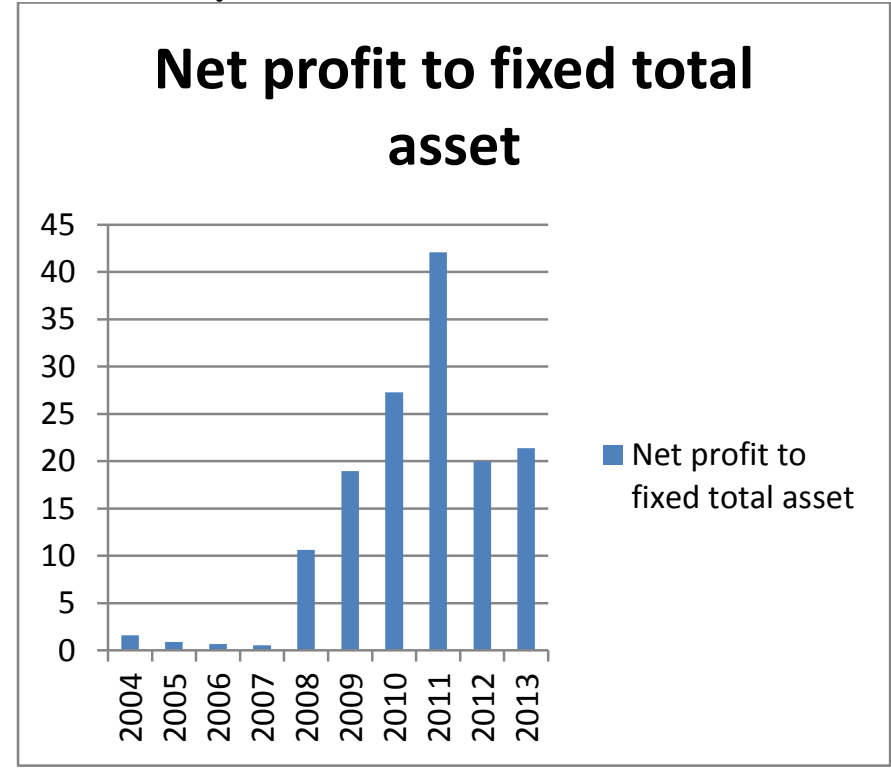

Operating Ratio: The smaller the ratio, the greater the organization's ability to generate profit if revenues decrease. When using this ratio, however, investors should be aware that it doesn't take debt repayment or expansion into account.

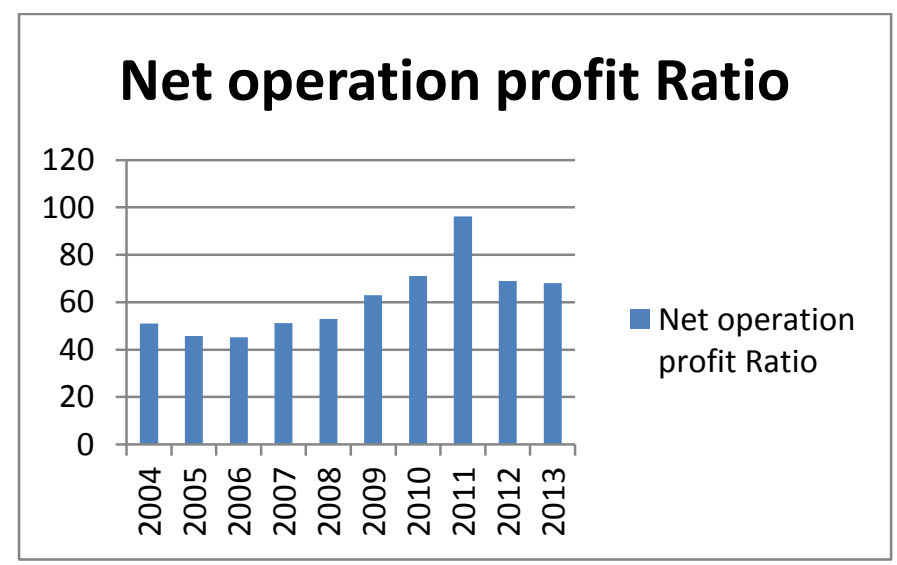

Profitability Ratios: A class of financial metrics that are used to assess a business's ability to generate earnings as compared to its expenses and other relevant costs incurred during a specific period of time. For most of these ratios, having a higher value relative to a competitor's ratio or the same ratio from a previous period is indicative that the company is doing well.

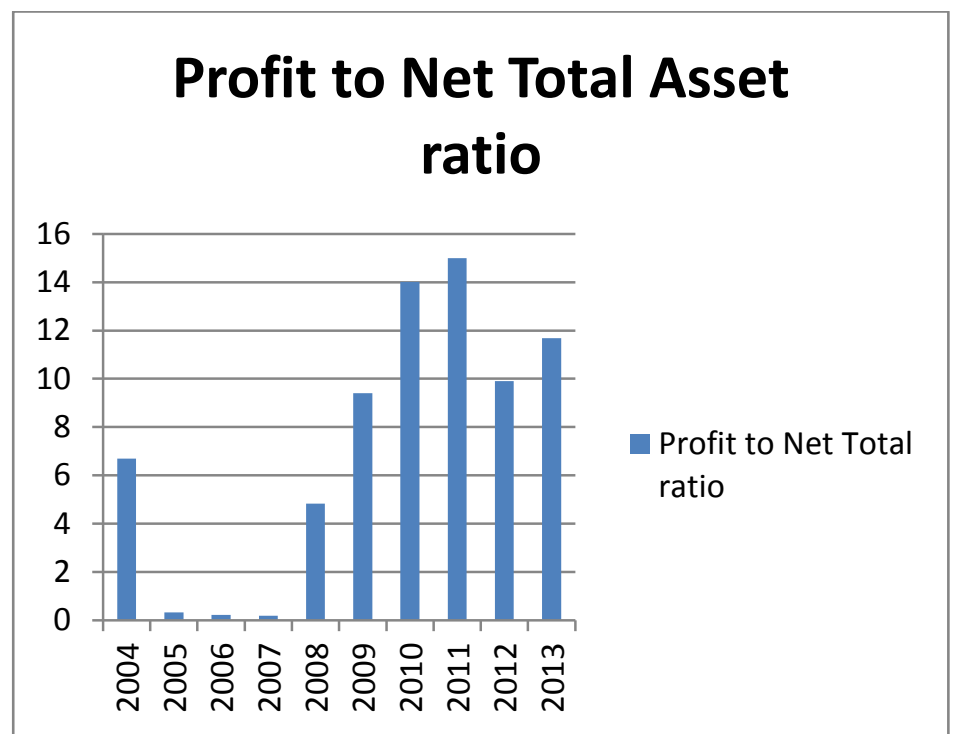

Cash to current liability ratio:

A ratio calculated by dividing a company's cash and marketable securities by its current liabilities. It demonstrates the company's ability to satisfy short-term financial obligations.

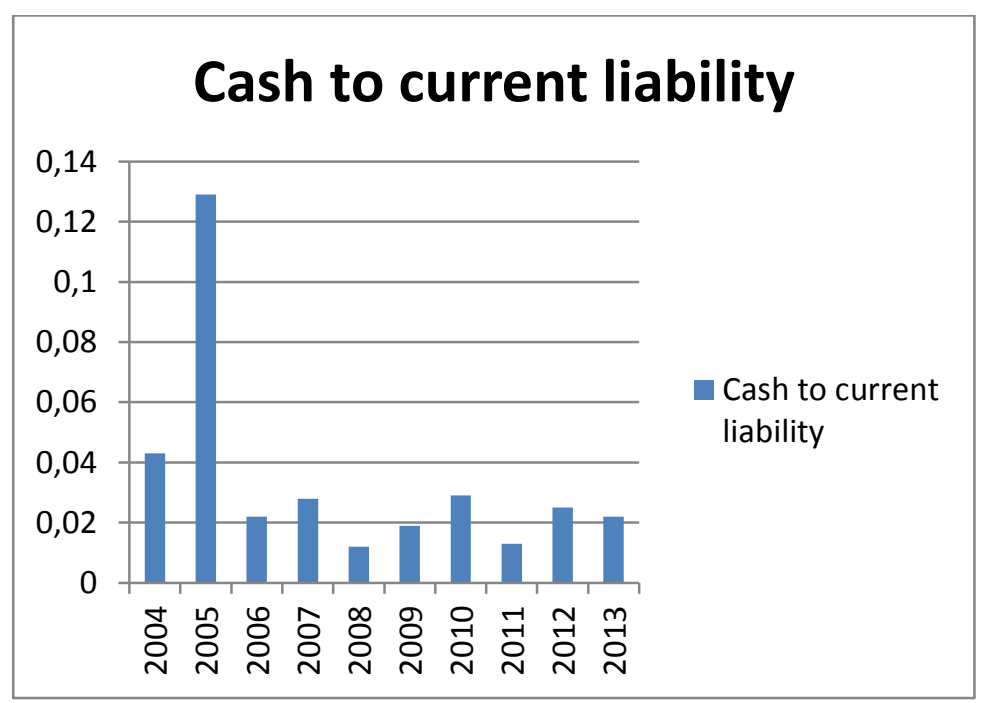

Dividend Yield ratio:

A financial ratio that shows how much a company pays out in dividends each year relative to its share price. In the absence of any capital gains, the dividend yield is the return on investment for a stock. Dividend yield is calculated as follows: 


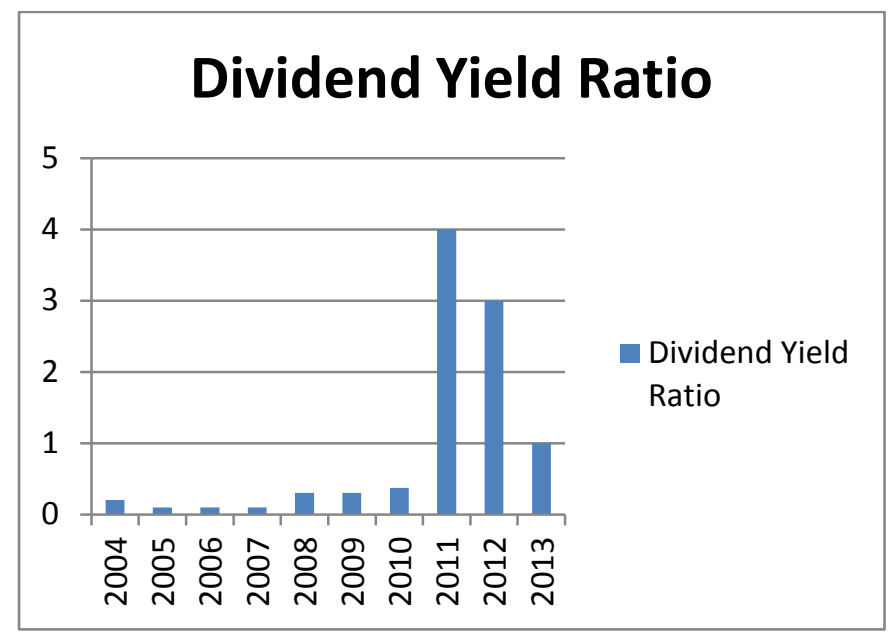

Working Capital ratio:

The working capital ratio (Current Assets/Current Liabilities) indicates whether a company has enough short term assets to cover its short term debt. Anything below 1 indicates negative W/C (working capital). While anything over 2 means that the company is not investing excess assets. Most believe that a ratio between 1.2 and 2.0 is sufficient.
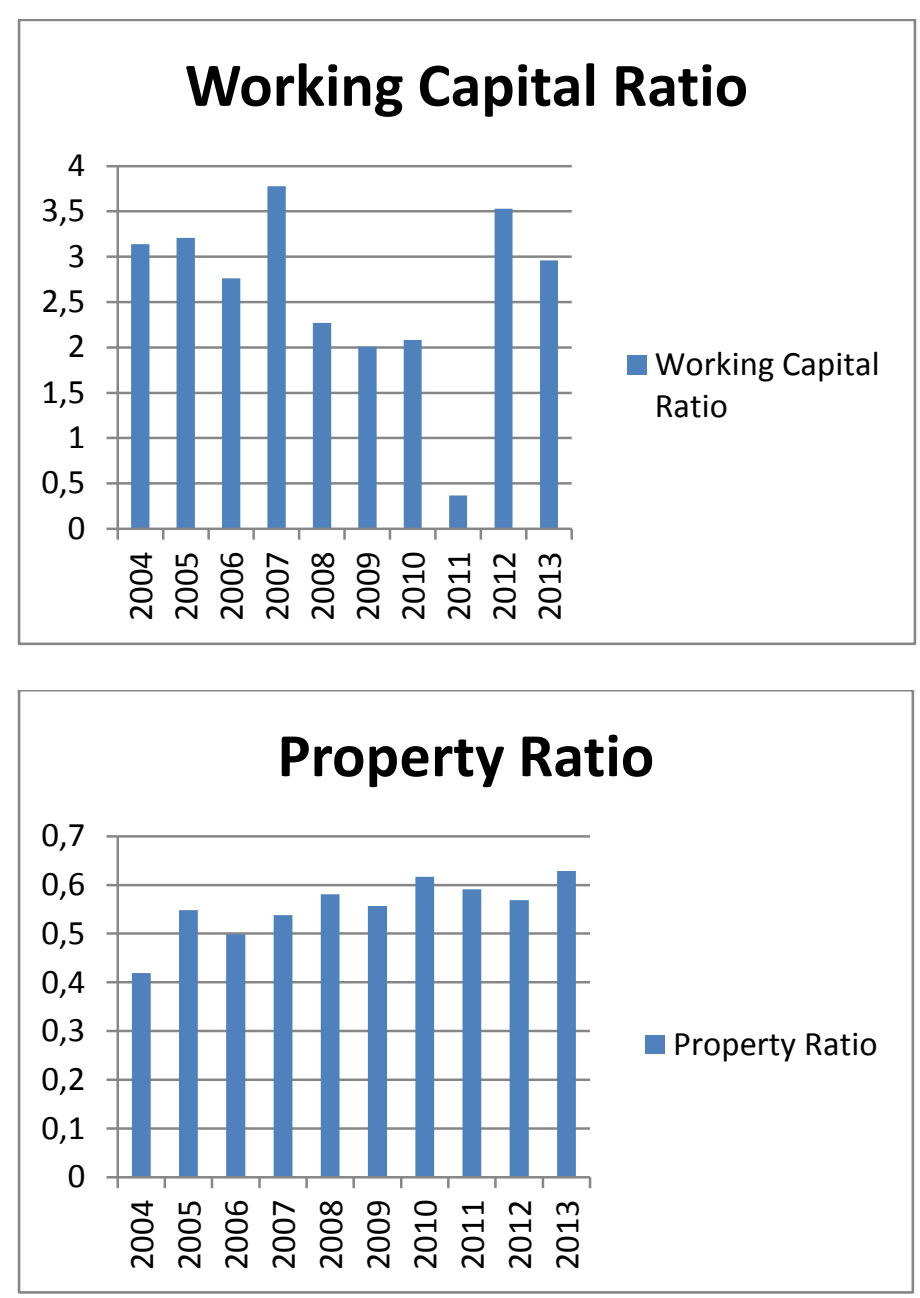

\section{Trend Analysis}

Trend analysis is the process of comparing business data over time to identify any consistent results or trends. We can develop a strategy to respond to these trends in line with our business goals. Trend analysis calculates the percentage change for one account over a period of time of two years or more. From the trend analysis we can get a clear idea about what change is occurred is response to some consecutive year. From the trend of Eastland insurance company Ltd we can get a clear picture of gross premium Net premium, net profit before and after tax and net incurred claim.

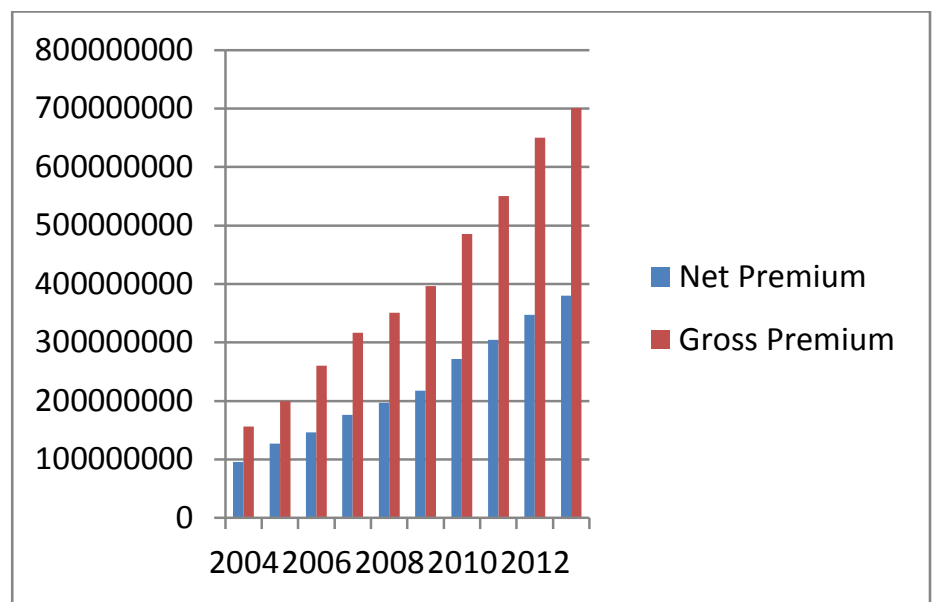

Figure represents that gross premium corresponding net premium over a period of time. The figure shows that the gross premium and net premium are gradually increasing.

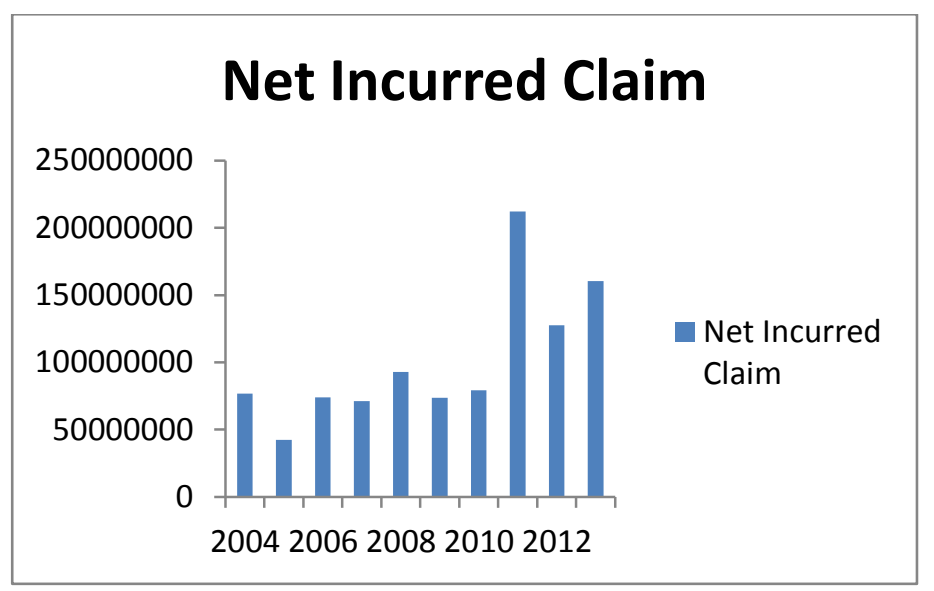

The figure number 2 represents net incurred claim over a period of time. The net incurred claim denotes a sequence of increase and decrease of net claim over the period but there is a significant increase of claim in the year 2011.

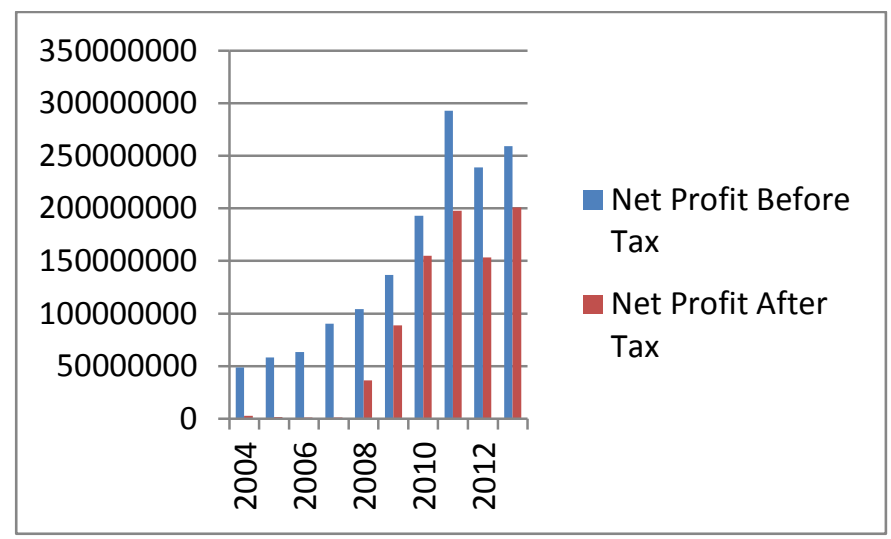

The figure 3 represents the relationship between net profit after tax and net profit before tax. During the first 4 year the net profit 
after tax is same but in rest of the year we have noticed some variations. The profit before tax is increasing gradually up to 2010 and a significant increase in 2011 but in the next two years we see a slight variation in net profit before tax.

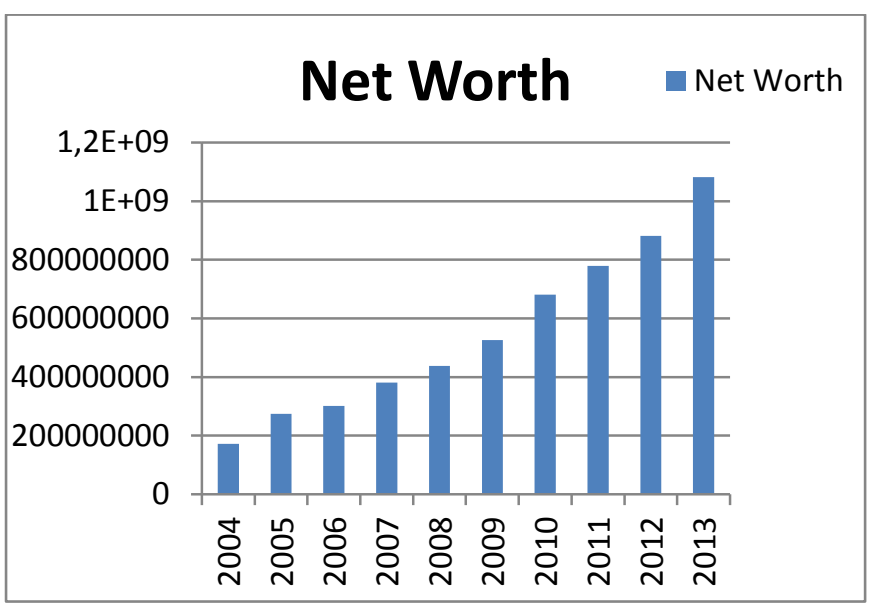

The last figure represents net worth over a certain period of time. We notice in the above trend that the net worth is gradually increasing.

8. Comparative efficiency measurements between Eastland Insurance Company Ltd. and Agroni Insurance Limited

Table 3: Ratio analysis of Eastland Insurance Company Ltd.

\begin{tabular}{|l|l|l|l|l|l|l|l|l|l|l|}
\hline Ratios/Year & $\mathbf{2 0 0 4}$ & $\mathbf{2 0 0 5}$ & $\mathbf{2 0 0 6}$ & $\mathbf{2 0 0 7}$ & $\mathbf{2 0 0 8}$ & $\mathbf{2 0 0 9}$ & $\mathbf{2 0 1 0}$ & $\mathbf{2 0 1 1}$ & $\mathbf{2 0 1 2}$ & $\mathbf{2 0 1 3}$ \\
\hline Gross profit Ratio & 38.22 & 42.82 & 31.84 & 49.45 & 44.42 & 49.05 & 62.88 & 80.23 & 61.16 & 63.27 \\
\hline $\begin{array}{l}\text { Net operation profit } \\
\text { Ratio }\end{array}$ & 50.94 & 45.80 & 45.15 & 51.25 & 52.95 & 62.92 & 71.00 & 96.24 & 68.86 & 68.13 \\
\hline $\begin{array}{l}\text { Return on capital } \\
\text { Employed ratio }\end{array}$ & 81.17 & 64.62 & 58.75 & 69.21 & 63.75 & 64.42 & 69.83 & 77.42 & 63.17 & 52.68 \\
\hline $\begin{array}{l}\text { Profit to Net Total } \\
\text { ratio }\end{array}$ & 6.69 & 0.33 & 0.22 & 0.19 & 4.84 & 9.40 & 14.01 & 14.99 & 9.91 & 11.68 \\
\hline $\begin{array}{l}\text { Net profit to fixed } \\
\text { total asset }\end{array}$ & 1.60 & 0.89 & 0.66 & 0.53 & 10.63 & 18.94 & 27.28 & 42.10 & 19.97 & 21.36 \\
\hline Current ratio & 4.14 & 4.20 & 3.75 & 4.77 & 3.26 & 3.01 & 3.08 & 1.37 & 4.53 & 3.96 \\
\hline Acid Test Ratio & 3.14 & 3.21 & 2.76 & 3.78 & 2.27 & 2.01 & 2.08 & 0.366 & 3.53 & 2.96 \\
\hline $\begin{array}{l}\text { Cash to current } \\
\text { liability }\end{array}$ & 0.043 & 0.129 & 0.022 & 0.028 & 0.012 & 0.019 & 0.029 & 0.013 & 0.025 & 0.022 \\
\hline $\begin{array}{l}\text { Fixed asset turnover } \\
\text { Ratio }\end{array}$ & 0.556 & 0.687 & 0.711 & 0.684 & 0.573 & 0.463 & 0.479 & 0.648 & 0.452 & 0.405 \\
\hline $\begin{array}{l}\text { Turnover to total } \\
\text { asset Ratio }\end{array}$ & 0.232 & 0.253 & 0.272 & 0.249 & 0.261 & 0.229 & 0.246 & 0.230 & 0.224 & 0.221 \\
\hline Debt to equity Ratio & 1.36 & 1.02 & 1.07 & 0.940 & 0.744 & 0.837 & 0.715 & 0.415 & 0.937 & 0.811 \\
\hline $\begin{array}{l}\text { Debt total asset } \\
\text { Ratio }\end{array}$ & .709 & 0.709 & 0.711 & 0.600 & 0.599 & 0.634 & 0.599 & 0.222 & 0.644 & 0.625 \\
\hline $\begin{array}{l}\text { Dividend Yield } \\
\text { Ratio }\end{array}$ & 0.2 & 0.10 & 0.10 & 0.10 & 0.30 & 0.30 & 0.37 & 4 & 3.00 & 1.00 \\
\hline $\begin{array}{l}\text { Working Capital } \\
\text { Ratio }\end{array}$ & 3.14 & 3.21 & 2.76 & 3.78 & 2.27 & 2.01 & 2.08 & 0.366 & 3.53 & 2.96 \\
\hline Property Ratio & 0.419 & 0.548 & 0.499 & 0.538 & 0.581 & 0.557 & 0.617 & 0.591 & 0.569 & 0.629 \\
\hline
\end{tabular}

Table 4: Ratio Analysis of Agrani Insurance Company Ltd. from 2004 to 2013

\begin{tabular}{|l|l|l|l|l|l|l|l|l|l|l|l|}
\hline SN & Ratio & 2004 & 2005 & 2006 & 2007 & 2008 & 2009 & 2010 & 2011 & 2012 & 2013 \\
\hline 1. & Gross profit ratio & $9.78 \%$ & $\begin{array}{l}17.58 \\
\%\end{array}$ & $\begin{array}{l}38.74 \\
\%\end{array}$ & $\begin{array}{l}29.45 \\
\%\end{array}$ & $28.7 \%$ & $\begin{array}{l}31.25 \\
\%\end{array}$ & $\begin{array}{l}34.16 \\
\%\end{array}$ & $\begin{array}{l}31.21 \\
\%\end{array}$ & $\begin{array}{l}40.01 \\
\%\end{array}$ & $\begin{array}{l}43.77 \\
\%\end{array}$ \\
\hline 2. & Net profit ratio & $5.39 \%$ & $8.35 \%$ & $\begin{array}{l}25.04 \\
\%\end{array}$ & $\begin{array}{l}18.18 \\
\%\end{array}$ & $\begin{array}{l}16.65 \\
\%\end{array}$ & $\begin{array}{l}20.58 \\
\%\end{array}$ & $\begin{array}{l}23.82 \\
\%\end{array}$ & $\begin{array}{l}22.61 \\
\%\end{array}$ & $\begin{array}{l}27.43 \\
\%\end{array}$ & $\begin{array}{l}29.45 \\
\%\end{array}$ \\
\hline 3. & $\begin{array}{l}\text { Return on capital } \\
\text { employed ratio }\end{array}$ & $6.23 \%$ & $7.91 \%$ & $\begin{array}{l}11.78 \\
\%\end{array}$ & $\begin{array}{l}11.49 \\
\%\end{array}$ & $\begin{array}{l}11.78 \\
\%\end{array}$ & $\begin{array}{l}13.28 \\
\%\end{array}$ & $\begin{array}{l}16.26 \\
\%\end{array}$ & $\begin{array}{l}13.26 \\
\%\end{array}$ & $\begin{array}{l}17.14 \\
\%\end{array}$ & $\begin{array}{l}15.76 \\
\%\end{array}$ \\
\hline 4. & $\begin{array}{l}\text { Profit to net total } \\
\text { asset ratio }\end{array}$ & $2.55 \%$ & $2.97 \%$ & $5.78 \%$ & $4.84 \%$ & $4.78 \%$ & $6.40 \%$ & $8.21 \%$ & $6.88 \%$ & $8.25 \%$ & $7.47 \%$ \\
\hline 5. & Net profit to fixed & 75.61 & 164.21 & 196.99 & 162.81 & 124.13 & 154.07 & 69.69 & 24.23 & 33.10 & 28.39 \\
\hline
\end{tabular}




\begin{tabular}{|c|c|c|c|c|c|c|c|c|c|c|c|}
\hline & asset ratio & $\%$ & $\%$ & $\%$ & $\%$ & $\%$ & $\%$ & $\%$ & $\%$ & $\%$ & $\%$ \\
\hline 6. & Current ratio & $1.18 \mathrm{t} 1$ & $\begin{array}{ll}1.33 \mathrm{t} \\
1\end{array}$ & $\begin{array}{ll}1.20 \mathrm{t} \\
1\end{array}$ & $\begin{array}{ll}1.29 \mathrm{t} \\
1\end{array}$ & $\begin{array}{ll}1.25 \mathrm{t} \\
1\end{array}$ & $\begin{array}{ll}1.64 \mathrm{t} \\
1\end{array}$ & $\begin{array}{ll}1.39 \mathrm{t} \\
1\end{array}$ & $\begin{array}{ll}0.95 & \mathrm{t} \\
1 & \end{array}$ & $\begin{array}{ll}0.83 \quad \mathrm{t} \\
1\end{array}$ & $\begin{array}{ll}0.85 \quad \mathrm{t} \\
1\end{array}$ \\
\hline 7. & Acid test ratio & $\begin{array}{ll}0.18 \quad \mathrm{t} \\
1\end{array}$ & $\begin{array}{ll}0.33 \quad \mathrm{t} \\
1\end{array}$ & $\begin{array}{ll}0.20 \mathrm{t} \\
1\end{array}$ & $\begin{array}{ll}0.29 \mathrm{t} \\
1\end{array}$ & $\begin{array}{ll}0.25 \quad \mathrm{t} \\
1\end{array}$ & $\begin{array}{ll}0.63 \quad \mathrm{t} \\
1\end{array}$ & $\begin{array}{ll}0.39 \quad \mathrm{t} \\
1\end{array}$ & $\begin{array}{ll}0.18 \quad \mathrm{t} \\
1\end{array}$ & $\begin{array}{ll}1.14 \mathrm{t} \\
1\end{array}$ & $\begin{array}{ll}1.03 \mathrm{t} \\
1\end{array}$ \\
\hline 8. & $\begin{array}{l}\text { Cash to current } \\
\text { liability ratio }\end{array}$ & 2.13 & 3.21 & 2.38 & 1.97 & 1.79 & 1.71 & 1.47 & 1.70 & 1.43 & 1.38 \\
\hline 9. & $\begin{array}{l}\text { Fixed asset } \\
\text { turnover ratio }\end{array}$ & $\begin{array}{l}17.43 \\
\text { Times }\end{array}$ & $\begin{array}{l}25.08 \\
\text { Times }\end{array}$ & $\begin{array}{l}12.87 \\
\text { Times }\end{array}$ & $\begin{array}{l}14.32 \\
\text { Times }\end{array}$ & $\begin{array}{l}12.11 \\
\text { Times }\end{array}$ & $\begin{array}{l}13.07 \\
\text { Times }\end{array}$ & $\begin{array}{l}5.73 \\
\text { Times }\end{array}$ & $\begin{array}{l}2.18 \\
\text { Times }\end{array}$ & $\begin{array}{l}1.95 \\
\text { Times }\end{array}$ & $\begin{array}{l}1.71 \\
\text { Times }\end{array}$ \\
\hline 10. & $\begin{array}{l}\text { Turn over to total } \\
\text { asset ratio }\end{array}$ & $\begin{array}{l}0.59 \\
\text { Times }\end{array}$ & $\begin{array}{l}0.45 \\
\text { Times }\end{array}$ & $\begin{array}{l}0.38 \\
\text { Times }\end{array}$ & $\begin{array}{l}0.43 \\
\text { Times }\end{array}$ & $\begin{array}{l}0.47 \\
\text { Times }\end{array}$ & $\begin{array}{l}0.54 \\
\text { Times }\end{array}$ & $\begin{array}{l}0.64 \\
\text { Times }\end{array}$ & $\begin{array}{l}0.62 \\
\text { Times }\end{array}$ & $\begin{array}{l}0.48 \\
\text { Times }\end{array}$ & $\begin{array}{l}0.45 \\
\text { Times }\end{array}$ \\
\hline 11. & $\begin{array}{l}\text { Debt to equity } \\
\text { ratio }\end{array}$ & $0.60 \mathrm{t} 1$ & $\begin{array}{ll}0.36 \quad \mathrm{t} \\
1\end{array}$ & $\begin{array}{ll}0.48 \quad \mathrm{t} \\
1\end{array}$ & $\begin{array}{ll}0.62 \quad \mathrm{t} \\
1\end{array}$ & $\begin{array}{ll}0.61 \quad \mathrm{t} \\
1\end{array}$ & $\begin{array}{ll}0.46 \quad \mathrm{t} \\
1\end{array}$ & $\begin{array}{ll}0.47 & \mathrm{t} \\
1 & \\
\end{array}$ & $\begin{array}{ll}0.48 \quad \mathrm{t} \\
1\end{array}$ & $\begin{array}{ll}0.51 & \mathrm{t} \\
1 & \\
\end{array}$ & $\begin{array}{ll}0.49 \quad \mathrm{t} \\
1\end{array}$ \\
\hline 12. & $\begin{array}{l}\text { Debt to total asset } \\
\text { ratio }\end{array}$ & $\begin{array}{ll}0.55 \quad \mathrm{t} \\
1\end{array}$ & $\begin{array}{ll}0.42 \quad \mathrm{t} \\
1\end{array}$ & $\begin{array}{ll}0.52 \mathrm{t} \\
1\end{array}$ & $\begin{array}{ll}0.58 \quad \mathrm{t} \\
1\end{array}$ & $\begin{array}{ll}0.60 \quad \mathrm{t} \\
1\end{array}$ & $\begin{array}{ll}0.53 \quad \mathrm{t} \\
1\end{array}$ & $\begin{array}{ll}0.55 & \mathrm{t} \\
1 & \end{array}$ & $\begin{array}{ll}0.56 \quad \mathrm{t} \\
1\end{array}$ & $\begin{array}{ll}0.59 & \mathrm{t} \\
1 & \end{array}$ & $\begin{array}{ll}0.59 \mathrm{t} \\
1\end{array}$ \\
\hline 13. & $\begin{array}{l}\text { Dividend yield } \\
\text { ratio }\end{array}$ & $5 \%$ & $5 \%$ & $7 \%$ & $7 \%$ & $10 \%$ & $10 \%$ & $10 \%$ & $10 \%$ & $10 \%$ & $10 \%$ \\
\hline 14. & $\begin{array}{l}\text { Working capital } \\
\text { ratio }\end{array}$ & $\begin{array}{ll}0.19 \mathrm{t} \\
1\end{array}$ & $\begin{array}{ll}0.33 \quad \mathrm{t} \\
1\end{array}$ & $\begin{array}{ll}0.29 \mathrm{t} \\
1\end{array}$ & $\begin{array}{ll}0.51 & \mathrm{t} \\
1 & \end{array}$ & $\begin{array}{ll}0.42 \quad \mathrm{t} \\
1\end{array}$ & $\begin{array}{ll}0.65 \quad \mathrm{t} \\
1\end{array}$ & $\begin{array}{ll}0.41 & \mathrm{t} \\
1 & \end{array}$ & $\begin{array}{ll}0.19 \mathrm{t} \\
1\end{array}$ & $\begin{array}{ll}1.16 \mathrm{t} \\
1\end{array}$ & $\begin{array}{ll}1.08 \mathrm{t} \\
1\end{array}$ \\
\hline 15. & $\begin{array}{l}\text { Price earnings } \\
\text { ratio }\end{array}$ & 19.30 & 16.83 & 8.29 & 14.08 & 9.09 & 8.26 & 5.71 & 7.35 & 5.78 & 7.24 \\
\hline
\end{tabular}

Gross profit Ratio: By observing above data, we have found that average gross profit ratio of Eastland Insurance Company Ltd. is $\mathbf{5 2 . 3 3 4}$ which is higher than the average gross profit ratio (30.47) of Agrani co. GPR of Eastland Insurance Company Ltd..is better than that of Agrani Co. as the ratio indicates that the higher the ratio the better is considered.

Net Profit Ratio: By observing above data, we have found that average net profit ratio of Eastland Insurance Company Ltd. is 61.324 which is higher than the average net profit ratio (19.75) of Agrani Co. NPR of Eastland Insurance Company Ltd..is better than that of Agrani Co. as the ratio indicates that the higher the ratio the better is considered.

Return on Capital Employed Ratio: After considering the above mentioned data, we have noticed that the average ROCE of Eastland Insurance Company Ltd. is 66.504 which is higher than that of Agrani Inc. Co. (12.43).Eastland Inc. Co. has efficiently used its capital.

Profit to Net total asset Ratio: After taking into consideration the above mentioned data we have reached a decision that the profitability on asset of Eastland Insurance Company Ltd. is better than the Agrani Inc. Co. as shows the average ratio 7.226 and 5.81 respectively.

Net Profit to Fixed Asset Ratio: By observing the above data, we have found that the condition of profitability on fixed asset of Eastland Insurance Company Ltd. is worse than that of Agrani Inc. Co. as shows the average ratio 14.396 and 103.32 respectively.

Current Ratio: On the basis of above data we have found that Eastland Inc. Co. is more capable of paying its obligations than Agrani Inc. Co. because the CR of Eastland Inc. CO. is higher than Agrani Inc. Co. their average ratios are 3.607 and 1.07.

Acid Test Ratio: By observing the above data we can say that Eastland Insurance Company Ltd. has more capability to cover its immediate liability as its average ATR is 2.6106 than Agrani Inc. Co. as its ratio is 0.462 .
Cash To Current Liability Ratio: Based on above data it is found that the Eastland Insurance Company Ltd. is not capable enough to meet up its short term financial obligations as its average CTCLR is 0.0342 . On the other hand the Agrani Inc. Co. is capable enough to cover the short term financial obligations as its average ratio (1.917) indicates better condition.

Fixed Asset Turnover Ratio: After observing the above data it is found that Agrani Inc. Co. has managed its fixed asset more effectively in generating revenues than the Eastland Insurance Company Ltd. as the rational situation is less than that of Agrani Inc. Co. Their average ratios are 0.5658 and 11.045 respectively.

Total Asset Turnover Ratio: By observing above data, we have found that Total Asset Turnover Ratio of Eastland Insurance Company Ltd. is 0.2422 which is less than the average Total Asset Turnover Ratio (0.505) of Agrani co. Total Asset Turnover Ratio of Eastland Insurance Company Ltd..is worse than that of Agrani Co. as the ratio indicates that the higher the ratio the better is considered.

Debt to Equity Ratio: On the basis of above data we have found that Eastland Insurance Company Ltd. is in more risk than the Agrani Inc. Co. because as Agrani's ratio indicates it has used lees debt than Eastland Insurance Company Ltd. since using more debt means more risk. Their average ratios are 0.8849 and 0.508 respectively.

Debt to Asset Ratio: On the basis of above data we have found that Eastland Insurance Company Ltd. is in less risk than the Agrani Inc. Co. because as Agrani's ratio indicates it has used more asset than Eastland Insurance Company Ltd. since using more debt means more risk. Their average ratios are 0.6042 and 0.537 respectively.

Dividend Yield Ratio: After observing the above data it is found that Agrani Inc. Co. has managed to gain higher dividend on per share than the Eastland Insurance Company Ltd. as the rational situation is less than that of Agrani Inc. Co. Their average ratios are 0.947 and 8.4 respectively. 
Working capital Ratio: Based on above data it is found that the Eastland Insurance Company Ltd. is capable enough to meet up its short term debt with short term asset as its average WCM is 2.6106.On the other hand the Agrani Inc. Co. is not capable enough to cover the short term debt with short term asset as its average ratio ( 0.524$)$ indicates better condition

\section{Potentials and problems of Eastland Insurance in Bangladesh}

Insurance is a system of spreading the risk of one to the shoulders of many. It can be defined as a co-operative device to spread the loss caused by a particular risk over a number of persons who are exposed to it and who agree to ensure themselves against that risk. It is a contract whereby the insurers, on receipt of a consideration known as premium, agree to indemnify the insured against losses arising out of certain specified unforeseen contingencies or perils insured against. It can play an important role in a country's economy. It is an old form of financial practice of sharing risk, which was introduced in this area in mid18th century. From the following we will know about the insurance business's potentials, problems and prospects in Bangladesh.

The insurance industry of Bangladesh has witnessed a steady growth and attracted a lot of interest in recent years. Even then, the industry is ripe with problems. This study is a reflection of the severity and likelihood of the problems and prospects of the insurance industry from the viewpoint of the insurance companies themselves. The study revealed that low qualification of the agents to be the most pressing human resource management problem while the lack of technical employees stood as the most important operational problem. Customers' lack of understanding of insurance terms and policies and unhealthy competition came out to be the most severe marketing and ethical problems respectively. Only human resource management problems were found to vary in their degree of severity among life and general insurance companies; these problems proved to be more critical for the life insurance companies, especially the state-owned ones. State-owned life insurance Company is also the greatest sufferer of marketing, operational and ethical problems among all categories of life insurance companies.

With economic expansion of the country the potential for this industry is quite high. With higher income and literacy rate, people are expected to recognize the benefits of insurance in life business and thus raising the demand of insurance services. Higher demand for insurance, merger of the insurance companies and higher underwriting capacity of the insurance companies were judged to be the most likely prospects. Furthermore, there is a high likelihood in the growth of fire and marine insurance, and micro-insurance services. In order to stimulate the demand, effective marketing initiatives with ethical competition needs to be undertaken. In addition to that recruitment of more qualified employees at management level, proper training and orientation of the agents/employees, development of information technology, service diversification within the industry, fully functioning regulatory system, etc., are essential.

In a developing country like Bangladesh, insurance companies are playing a very important role in economy. Though insurance industry has a very prospect in the economy but for some reasons it is totally failed to achieve its goal. If we want to know the reasons behind this then we should look forward the following according to Eastland Insurance Company Ltd. The problems have been categorized in different levels and they are; social, economic. Political, legal and others problems.

\section{Social Problems}

\section{a) Less Public awareness}

A vast majority of people especially in rural areas are left outside the insurance coverage. This mainly results from the unawareness among the people. Even a large portion of people don "et have the minimum idea of insurance. People are not aware of the benefits from the insurance policy and a great number of people believe that insurance business is nothing but cheating and assume that insurance policy is quite unnecessary. This negative attitude from the people is lessening the importance of absorbing insurance policy in a large extent.

\section{b) Centralization}

Most of the insurance companies in our country are located in urban areas and there are few branches in rural areas. They think that they might have better scope for performing their business as the economic condition of the urban is better than the rural areas. They don't think that the large number of our population reside in rural areas and if branches are expanded in rural areas then the business can thrive if proper motivation policy is taken to aware the mass people of the rural areas. Thus this centralization policy acts as an obstruction for the growth of insurance business in our country.

\section{c) Illiteracy}

Mass illiteracy is another factor that adversely affects the marketing of Eastland insurance Company. About $70 \%$ of the population is floating in the sea of ignorance. Illiteracy leads one to think that the insurance is deception; it is no value in life. They cannot think rationality because they do not know what is insurance and what its importance as security for future.

\section{d) Religious and social superstition}

Religious attitude of the people also stands against efficient Eastland insurance. The religious people believe that the future is uncertain, it is in the hand of Allah and they do not think it necessary to buy insurance policy for them.

\section{e) Lack of awareness of mass people}

Insurance awareness is poor. Agents are not skilled enough. These agents cannot perform their job properly to make the people aware of facilities of insurance.

\section{Economic Problems}

\section{a) Poor economic conditions}

Bangladesh is one of the poorest countries in the world and most of the people in this country live under extreme poverty level. All of these people fight hard to earn their livelihood and are marginal in relation to the expenditure with the income. It is quite impossible for them to save some money for future need. Therefore they are quite unable to give the amount to the insurer which is called as premium and regarded as safety or precautionary measures against any accident. The number of people who can bear the premium to the insurance company is very few in regard to those mentioned above. Therefore the overall poor economic condition is creating obstacle to flourish the insurance business in Bangladesh

\section{b) Higher cost of business}

Growing cost of business is another problem that insurance companies are facing now day. They urge that government tax, 
house rent, utility, commission fee, stationeries are growing day by day. But their businesses are not growing so fast with that rate. Besides this the policy holders are not willing to pay too much premium with growing cost that is hampering the strategies of insurance companies. So they are facing difficulties in running their business efficiently.

\section{c) Low per capita income}

Poor economic condition is considered to be the main reason for both general insurance and life insurance penetration in Bangladesh. The country has a very low per capita income and over $50 \%$ of our total population lives below the poverty line. Inability to save or negligible savings by a vast majority of population kept them away from the horizon of insurance.

\section{d) Poor income and savings}

People have a very small saving potentially and thus have less or no disposable income. Almost the whole of the income is exhausted in the process of maintaining the day-to-day life. Thus they are left with little amount, which may not deemed to sufficient for the payment of premiums. This factor discourages many to buy insurance policy.

\section{e) Shortage of fund}

Eastland insurance company tries to control price spiral more than other insurance company for the betterment of policyholder and it does not usually increase insurance premium. Most of the policyholders cannot continue their policies owing to uncertain price spiral and their shortage of fund.

\section{Political problems}

\section{a) Political instability}

Political instability is a major problem in Bangladesh. For the instability in politics, many disruptive situations are often created which are bad for any businesses. The people who operate various businesses in our country often experience various types of inconvenience in running their business. Insurance business is not an exception 0of this. Political instability and inconsistency of political courses are a serious problem for the insurance business.

\section{b) Lack of supervision from the government}

Lack of surveillance from government ministry encourages many insurance companies to follow some unethical practices like make harassment to policy holder and showing less in the financial statement. This not only destroying the reputation of the well-known insurance companies but also creates negative impact in the mind of the people about insurance. Besides this government sometimes impose some conflicting rules and regulation without discussing with insurance companies governing body. It creates conflict among insurance companies with government and act as one of the main hindrances of growing insurance business.

\section{c) Problem of planning and administration}

After the change of the government, the whole planning and administrative measures are changed which is the main constraint for long term plans. Without long term planning any permanent development or solution of existing problems are impossible

\section{Legal Problems}

\section{a) Too much complexity}

To take an insurance policy there are great number of rules and regulations which must be compelled by the insured person. And into those rules a vast number of complexities is present there.
Therefore the people are discouraged to take insurance policy because they think that the complexities will create extra pressure on their mind which may hamper other jobs.

\section{b) Poor knowledge of agents}

The marketing of insurance is greatly hampered in the remote village of Bangladesh where the agents are appointed from respected locality. This is because; educated young people are seemed to be reluctant to become insurance agents. Therefore, persons finding no job or persons having lesser knowledge become insurance agents whom cannot acquaint themselves fully with the whereabouts of insurance. Such agents cannot play efficient role in convincing a potential policyholder.

\section{Other problems}

\section{a) Negligence of policy holders}

People of Bangladesh being unaware and being enforced by social and religious superstition, they are unwilling to take insurance policy. Although some people take insurance, many of the policyholders are negligent to pay premium in time and sometimes they stop payment totally.

\section{b) Lack of training for the employees}

Spread of insurance business in Bangladesh failed for lack of proper training by the employees specially the field employees of insurance companies. Still there are not enough training center to provide proper training regarding insurance activities for the officials of insurance company. Though there is one insurance training center in Bangladesh it totally failed to achieve its target in insurance field.

\section{c) Absence of business ethics}

Some insurance companies create harassment on the policy holders or sometimes on the dependents of the policy holders when they want back their money after death or maturity. The insurance companies show different causes in order to make delay to return back the money at expected time. Sometimes they are eager to pay less than the desired amount by creating various circumstances such as they try to say that the disaster of the subject matter of the policy is not responsible due to their activities. Besides this some field officials also create some illegal acts.

\section{d) Lack of marketing policy}

One of the major problems in insurance company is lack of marketing policy. Management is not taking initiative to increase their marketing expansion. They provide tiny amount advertisement, which is not sufficient for increasing business development.

\section{e) Lack of reliability}

Peoples have lacking of reliability on the insurance company, because many insurance companies do not make payment they agree to pay in time of selling policy to the people.

\section{Prospects of insurance business in Bangladesh}

As well as the problems mentioned above, there are many good signs for the insurance business in Bangladesh. The factors that can facilitate the insurance business in our country are discussed below. These facts can be measured as the prospective fields for insurance business in Bangladesh.

\section{a) Increase GDP rate}

The GDP of our country is increasing than the previous years which results in increase of per capita income. So this growing 
GDP and income holds bright prospects for insurance companies. The major problem is the incapability of our people to pay the premium charged by the insurance companies. . With the growth in the income more and more people are now willing to take an insurance policy for safeguarding themselves from any danger.

\section{b) Opportunity for Increased population}

There is a big opportunity lies ahead for the insurance companies as the population of our country are increasing day by day. Although most of people of our country live under extreme poverty level and want to avoid insurance policy number of potential policy holders in Bangladesh is growing with growth of the population. There is somewhat relationship between growing populations with the number of public vehicle. As we know all public vehicle must have an insurance policy. So growing population also increase the motor insurance too. That is growth in population opens greater scope for every kind of insurance business that results in growing prospect for insurance companies.

\section{c) Insurance for new business}

There are so many new businesses starting every day and manufacturing sector is booming with global demand. Every business is insured under an insurance company to protect its company from any kind of accident. Therefore growing industry, mill, factories are creating better scope for the insurance companies to flourish their business.

\section{d) Developing mass awareness about insurance}

People are now much more conscious about their safety. So they are encouraged to take an insurance policy for making their life free from any unexpected occurrence. Increase in literacy rate is helping predominantly to create awareness among the people regarding taking insurance policy. Besides this insurance companies are also trying to eradicate the negative attitude of people towards the insurance company by organizing various programs such as seminars, programs including social responsibilities etc.

\section{Recommendation \& Conclusion}

Moreover, in a global economy characterized by rapid social and demographic change and by the emergence of new risks (e.g. by climate change or technological developments) and new needs (health care, pensions), cooperation between private insurance and public institutions is essential. This cooperation can bring benefits in many fields, for example, health of the working population, accident. According to a Swiss agency report, life insurance premium globally is expected to increase from $\$ 188$ billion in 2003 to $\$ 450$ billion by 2014 and non-life premium from $\$ 123$ billion to $\$ 250$ billion over the same period. The report has been identified great potential of insurance sector in the developing world. Insurance is a small but growing sector in Bangladesh. As component of service sector, its contribution to GDP is insignificant (less than 0.4\%). As of 2005-06, it comprises only one-fifth of the total domestic product produced by the financial service sector. However, its share as proportion to the GDP or to the financial service sector has been growing at a faster rate over the last decade. From around $10 \%$ of domestic product by the financial service sector, insurance sector's share increased to over $20 \%$ by $2001-02$ and has been maintaining around $22 \%$ till then. So we can certainly say that there are many positive aspects and it is contributing much to the economic development of a country. Thus it is helping in strengthening the economic condition to a large extent.
There are some sectors that require close attention and other things such as time and place. Eastland Insurance Company is a large company and it has to follow a lot of things and system which makes them little slow when it comes to prompt decision making.

We think that the following aspect should be taken under consideration to increase the customer satisfaction which ultimately helps Eastland Insurance Company Ltd. to be efficient in insurance business

- There is no alternative of quality service. Insurance being a service rendering entity must provide quick services. Policyholders are highly dissatisfied with service of JBC and SBC. Due to poor quality services, public corporations are losing market. In order to ensure their continuity, such corporation must pay adequate attention on their efficiency of rendering service.

- The government should eliminate the difficulty in licensing procedure and should not delay in the approval of new companies if all the requirements are fulfilled. It will help not only to increase volume of business but also enhance the efficiency of competing with other companies.

- The policy holders are very much worried about the settlement of claims. Ordinary people also consider it main constraint. Therefore, instance companies should settle the claims as quickly as possible to create a healthy public image. For this purpose the claim settlement procedure can be simplified and the insurers can provide proper written guidelines of claim settlement to the policyholders. IDRA can also fixed a specific time not more than one month to the insurance companies to settle their claim if required documents are submitted properly by the insured.

- As there are no standard for insurance industry both home office and field office in the area of designation, Agency office setup rule. Standard collection formulation and standard commission structure guided by govt. insurance authority increases the efficiency of insurance business.

- Insurance companies are incurring heave expenditures because to the huge staff and multi-tier organizational set up and also the increasing trend of prices of the necessary articles the materials etc. So management should be more efficient to reduce the expenses.

- $\quad$ People's confidence toward insurance can rise up by giving them actual benefits as stated in the insurance policy and their relationship with the sales personal and with the insurance company.

- Pricing of insurance product must be efficiently matched with the cost of living stretchers a country considering long term in factionary factors of financial aspect.

- The policy holders are very much worried about the settlement of claims. Ordinary people also consider it main constraint. Therefore, instance companies should settle the claims as quickly as possible to create a healthy public image. For this purpose the claim settlement procedure can be simplified and the insurers can provide proper written guidelines of claim settlement to the policyholders. IDRA can also fixed a specific time not more than one month to the insurance companies to settle their 
claim if required documents are submitted properly by the insured.

- $\quad$ Responsibility should be established to all employees according to their involvement in appraisal project.

- $\quad$ Both primary \& secondary database of the Eastland Insurance Company should be improved \& strengthened.

- $\quad$ Proper policy to be adopted and implemented.

Eastland Insurance Company Ltd. is a private owned company that has been working in the country as a leading general insurance company. It has a lot of responsibility as for being the biggest insurance sector their evidence of competency we can surely say that they are the future of general insurance sector in Bangladesh. Eastland Insurance Company Ltd. has the upper hand in the private sector. Where the owner needs profit from its own Eastland Insurance Company Limited's annual report showed the amount clearly. They are well figured amount that is being added to the fund of owner's wealth.

\section{References and notes}

01. Annual Report of Eastland Insurance Company Ltd.: 2004-2013.

02. Mishra, M.N. (2004), "Insurance Principles and Practice", Reprinted; New Delhi: S, Chand \& Company.

03. Oyatoye \& Arileserre (2012) "The Development of General Insurance Corporation” Insurance Business Review Vol.6.

04. Bhuiyan, B.A, Ali, K.M.M, Nurnnabi, M.A.A and Ahmed,T.(2003).conducted A study of "Relationships among Job Design Motivation and Performances of the Employees in the Insurance Sector of Bangladesh "Insurance Journal, Vol 54 (July).

05. Harrington, Niehaus, 2006, Risk Management \& Insurance, $2^{\text {nd }}$ Edition, Tata McGraw-Hill 